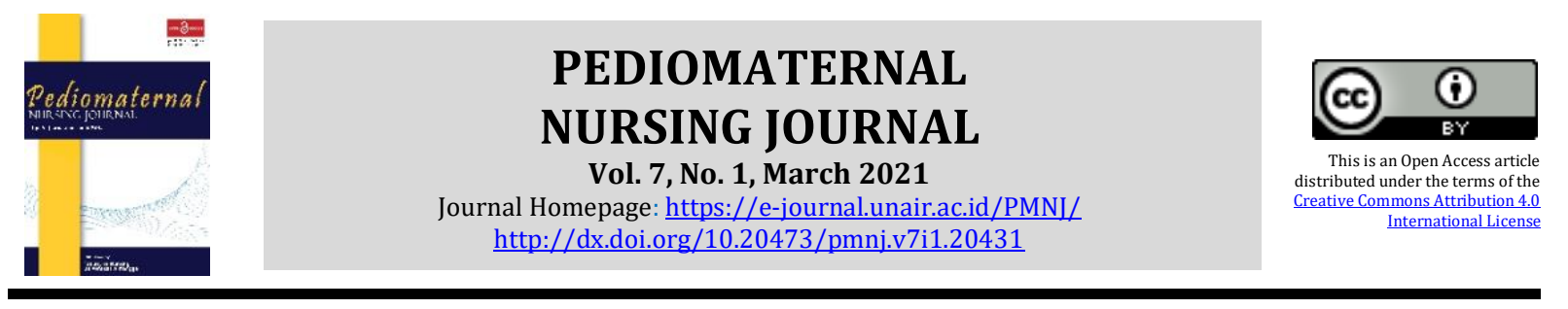

Original Research

\title{
Self-Structured Breast Cancer Awareness among Female Adolescent
}

\author{
Rahayu Dewi Pangestuti' ${ }^{1}$ Ni Ketut Alit Armini' ${ }^{2}$ (D) , Lingga Curnia Dewi ${ }^{3}$ \\ 1 Professional Nursing Program, Faculty of Nursing, Universitas Airlangga, Surabaya, Indonesia \\ 2 Maternity and Pediatric Nursing Department, Faculty of Nursing, Universitas Airlangga, Surabaya, Indonesia \\ ${ }^{3}$ Fundamental, Medical Surgical, and Critical Care Nursing Department Faculty of Nursing, Universitas Airlangga, \\ Surabaya, Indonesia
}

\section{ARTICLE HISTORY}

Received: July 2, 2020

Accepted: Sept 3, 2020

Published: July 18, 2021

\section{KEYWORDS}

breast cancer awareness; adolescence,; breast cancer

\section{CORRESPONDING AUTHOR}

Ni Ketut Alit Armini nk.alita@fkp.unair.ac.id Faculty of Nursing, Universitas Airlangga, Surabaya, Indonesia

Cite this as:

\begin{abstract}
Introduction: The incidence of breast cancer has increased every year, mostly in developing countries. However, breast cancer awareness in women is still insufficient. A woman must be aware of breast cancer disease earlier. This study aimed to describe breast cancer awareness in female adolescents.

Methods: The research design was used descriptive-analytic. The study population consisted of female adolescents in 10th-11th grade at Vocational High School in Surabaya, East Java, Indonesia. The sample was taken using stratified random sampling. There are 206 female adolescents aged 15-18 years old who participated in this study. Data collected using a self-structured breast cancer awareness questionnaire arranged by Breast Cancer Awareness Measurement (BCAM) guideline. The questionnaire consisted of breast cancer knowledge (disease, signs and symptoms, risk factors), perception, and BSE. The statistical analysis was using distribution frequency.
\end{abstract}

Results: The result presented that the majority of female adolescents had high awareness $(67,5 \%)$. The maximum score was knowledge of disease $(3.28 \pm 0.54)$ (table 3$)$. The minimum score was risk factors knowledge $(1.95 \pm 0.69)$ and BSE $(1.81 \pm 0.78)$.

Conclusion: The respondents have good knowledge of breast cancer disease yet understanding of risk factors is low. It is necessary to do counseling programs in school, particularly women's reproductive health and breast self-examination (BSE) due to improve knowledge of risk factors in female adolescents.

Pangestuti, R, D., Armini, N, K, A., \& Dewi, L, C. (2021). Self-Structured Breast Cancer Awareness among Female Adolescent Pediomaternal Nurs. J., 7(1), 1-7. Doi: http://dx.doi.org/10.20473/pmnj.v7i1.20431

\section{INTRODUCTION}

Breast cancer is the second most common disease which occurs in women in the world (Momenimovahed \& Salehiniya, 2019; WHO, 2019a). The prevalence of breast cancer has been increased every year in a developing country significantly. Breast cancer is one type of cancer that often occurs in Indonesian women. Breast cancer has a contribution of $30 \%$ and is the most dominating type of cancer in Indonesia (Kemenkes RI, 2018; 
Luzzati, Parenti, \& Rughi, 2018; WHO, 2019a). However, the awareness of breast cancer in women is low (Katkuri \& Gorantla, 2018; Mardela, Maneewat, \& Sangchan, 2017; Sama et al., 2017; Sayed et al., 2019). Some of the factors that cause low awareness in women namely lack knowledge, risk factors, signs and symptoms, and low BSE (Agbokey et al., 2019; Apriliyana, Agusyahbana, Mawarni, \& Nugroho, 2017; Katkuri \& Gorantla, 2018; Liu et al., 2018; Mahajan et al., 2019; Sama et al., 2017; Sayed et al., 2019; Singam \& Wirakusuma, 2017).

The breast cancer incidence rate is around 1,7 million in 2012 and improves approximately 2,1 million in 2018 (WHO, 2019a). In Indonesia, breast cancer is reported as the first ranked disease that occurs in women (WHO, 2019b). The insufficient awareness showed in a Vocational High School in Surabaya, which was as much as $60 \%$ did not aware of breast cancer disease (lack of disease knowledge, signs and symptoms, risk factors, and BSE).

Promotive and preventive programs are needed to reduce breast cancer risk in women. The government has been created a healthy lifestyle program called CERDIK (check-up regularly, quit smoking, increase physical activity, have healthy food, adequate rest, and manage stress), BSE, and breast clinical examination (Kemenkes RI, 2016). Likewise, the World Health Organization (WHO) has been created a Global Action Plan to reduce and prevent Non-Communicable Diseases by a healthy lifestyle and improving physical activity (WHO, 2010, 2013). However, those programs have been focused only on women aged 20 years old and above. Breast cancer awareness is needed not only for adult women but also for female adolescents since they got period. The awareness indicates knowledge, perception, and prevention due to breast cancer disease. This study's purpose was to the awareness of breast cancer in female adolescents.

\section{METHOD}

\subsection{Design}

The design was descriptive-analytic intending to describe the variable.

\subsection{Population, Samples, and Sampling}

The population in this study was 424 female students consisted of female adolescents aged 15-18 years old who attended 10th11th grade, a Vocational High School in Surabaya. The sample totaled 206 female students who were taken using stratified random sampling. The sample size was calculated according to the Slovin equation. Before the sampling technique was carried out, the target population was homogenized according to the inclusion criteria between the ages of 15-18 years, was able to communicate both verbally and in writing well. Exclusion criteria for this study were girls who had a history of tumors. Furthermore, the calculation of enormous proportions is carried out. Taking prospective respondents by asking for a list of names of all class 10th-11th grade students from the counseling teacher then using research randomizer software, the terms of students who are potential respondents are obtained.

\subsection{Variables}

The variable was breast cancer awareness in female adolescents.

\subsection{Instruments}

This research applied the socio-demography questionnaire to know the characteristics of the respondents and breast cancer awareness questionnaire, which is selfstructured by the researcher. The selfstructured questionnaire was modified according to the BCAM guideline (Cancer Research UK, 2009). The questionnaire consisted of knowledge, perception toward signs and symptoms, perception toward breast cancer risk. The female adolescents had high awareness if they scored $\geq$ mean, and they had low understanding if they scored $<$ mean. This questionnaire had been checked for validity and reliability test at 15 female adolescents in different populations. The Cronbach alpha was 0.970 .

\subsection{Procedure}

The first step was asking permission from the Faculty of Nursing at Airlangga University and the principal. The researcher recruited the respondents by requesting the list of female students in $10^{\text {th }}-11^{\text {th }}$ grade. Then they were taken using stratified random sampling. Sampling was done by paying attention to the population strata level for each class. The 
Table 1. Respondent characteristics ( $\mathrm{n}=206)$

\begin{tabular}{|c|c|c|}
\hline Characteristics & $\mathbf{n}$ & $\%$ \\
\hline \multicolumn{3}{|l|}{ Ages } \\
\hline 15 years old & 37 & 18 \\
\hline 16 years old & 64 & 31.1 \\
\hline 17 years old & 91 & 44.2 \\
\hline 18 years old & 14 & 6.8 \\
\hline \multicolumn{3}{|l|}{ Menarche } \\
\hline <12 years old & 38 & 18.4 \\
\hline 12-14 years old & 167 & 81.1 \\
\hline$>15$ years old & 1 & 0.5 \\
\hline \multicolumn{3}{|l|}{ Menstrual period } \\
\hline$<7$ days & 65 & 31.6 \\
\hline 7 days & 107 & 51.9 \\
\hline$>7$ days & 34 & 16.5 \\
\hline \multicolumn{3}{|l|}{ Have a family with breast cancer } \\
\hline Yes & 14 & 6.8 \\
\hline No & 192 & 93.2 \\
\hline \multicolumn{3}{|l|}{ Lived with } \\
\hline Parent & 182 & 88.3 \\
\hline Boarding house & 8 & 3.9 \\
\hline Other families (except parent) & 16 & 7.8 \\
\hline \multicolumn{3}{|l|}{ Monetary allowance /days (IDR) } \\
\hline$\leq 15.000$ & 157 & 76.2 \\
\hline$>15.000$ & 49 & 23.8 \\
\hline \multicolumn{3}{|l|}{ Family income /months (IDR) } \\
\hline$\leq 3.700 .000$ & 138 & 67 \\
\hline$>3.700 .000$ & 68 & 33 \\
\hline \multicolumn{3}{|l|}{ Information } \\
\hline Family & 35 & 17 \\
\hline Friends & 13 & 6.3 \\
\hline Public health & 24 & 11.7 \\
\hline School & 32 & 15.5 \\
\hline Internet/social media & 88 & 42.7 \\
\hline $\mathrm{TV} /$ radio & 14 & 6.8 \\
\hline
\end{tabular}

Table 2. Distribution of breast cancer awareness in female adolescents $(n=206)$

\begin{tabular}{lcc}
\hline Characteristics & $\mathbf{n}$ & $\mathbf{\%}$ \\
\hline Awareness & 67 & 32.5 \\
Low & 139 & 67.5 \\
High & & 139 \\
\hline
\end{tabular}

parents before participated in this study. Collecting data was held at school by helping counseling teachers. The researcher explained goals, the benefits and risks, the principal of confidentiality, the fact that it was voluntary, compensation, and the involvement of the adolescents in this study. The researcher screened the questionnaire before they collected it to ensure that there was no missing data.

\subsection{Analysis}

The analysis in this study was univariate. Univariate analysis was used due to the respondent characteristics by their sociodemography and awareness of breast cancer. frequency test.

\subsection{Ethical Clearance}

This study had received a clearance certificate from the Health Research Ethics Commission No. 1782-KEPK. This study has minimal risk and benefits namely knowing of breast cancer awareness for female adolescents. The research considered autonomy, anonymity, confidentiality, justice, and beneficence.

\section{RESULT}

The majority of the respondent aged 17 years old (44.2\%). More than half of adolescents menarche was $12-14$ years old $(81.1 \%)$ with 
Table 3. Distribution of respondent answer from breast cancer awareness questionnaire $(n=206)$

\begin{tabular}{|c|c|c|c|c|c|c|c|c|c|}
\hline \multirow[t]{2}{*}{ Questionnaires } & \multicolumn{2}{|c|}{$\begin{array}{l}\text { Strongly } \\
\text { disagree }\end{array}$} & \multicolumn{2}{|c|}{ Disagree } & \multicolumn{2}{|c|}{ Agree } & \multicolumn{2}{|c|}{$\begin{array}{l}\text { Strongly } \\
\text { agree }\end{array}$} & \multirow[t]{2}{*}{ Mean \pm SD } \\
\hline & $\mathbf{n}$ & $\%$ & $\mathbf{n}$ & $\%$ & $\mathbf{n}$ & $\%$ & $\mathbf{n}$ & $\%$ & \\
\hline An aggressive disease & 0 & 0 & 9 & 4.4 & 130 & 63.1 & 67 & 32.5 & $3.28 \pm 0.54$ \\
\hline Women can occur & 14 & 6.8 & 58 & 28.2 & 113 & 54.9 & 21 & 10.2 & $2.68 \pm 0.75$ \\
\hline Able to cure & 26 & 12.6 & 46 & 22.3 & 120 & 58.3 & 14 & 6.8 & $2.59 \pm 0.80$ \\
\hline Early diagnosed easier cured & 20 & 9.7 & 50 & 24.3 & 101 & 49.0 & 35 & 17.0 & $2.73 \pm 0.86$ \\
\hline Caused by fat & 52 & 25.2 & 117 & 56.8 & 34 & 16.5 & 3 & 1.5 & $1.95 \pm 0.69$ \\
\hline $\begin{array}{l}\text { Caused by high fat } \\
\text { consumption }\end{array}$ & 25 & 12.1 & 92 & 44.7 & 71 & 34.5 & 18 & 8.7 & $2.34 \pm 0.81$ \\
\hline $\begin{array}{l}\text { Lump painful as a sign and } \\
\text { symptom }\end{array}$ & 5 & 2.4 & 63 & 30.6 & 102 & 49.5 & 36 & 17.5 & $2.82 \pm 0.74$ \\
\hline $\begin{array}{l}\text { Change of nipple as a sign } \\
\text { and symptom }\end{array}$ & 70 & 34.0 & 74 & 35.9 & 44 & 21.4 & 18 & 8.7 & $2.05 \pm 0.95$ \\
\hline $\begin{array}{l}\text { Confidence to know the } \\
\text { nipple changing }\end{array}$ & 39 & 18.9 & 96 & 46.6 & 65 & 31.6 & 6 & 2.9 & $2.18 \pm 0.77$ \\
\hline $\begin{array}{l}\text { Have a family with breast } \\
\text { will increase the risk }\end{array}$ & 26 & 12.6 & 89 & 43.2 & 80 & 38.8 & 11 & 5.3 & $2.37 \pm 0.77$ \\
\hline $\begin{array}{l}\text { Earlier Menarche will } \\
\text { increase the risk }\end{array}$ & 37 & 18.0 & 147 & 71.4 & 19 & 9.2 & 3 & 1.5 & $1.94 \pm 0.57$ \\
\hline $\begin{array}{l}\text { Physical inactivity will } \\
\text { increase the risk }\end{array}$ & 41 & 19.9 & 46 & 22.3 & 81 & 39.3 & 38 & 18.4 & $2.56 \pm 1.01$ \\
\hline $\begin{array}{l}\text { Do BSE in } 20^{\text {th }} \text { years old and } \\
\text { above }\end{array}$ & 81 & 39.3 & 87 & 42.2 & 34 & 16.5 & 4 & 1.9 & $1.81 \pm 0.78$ \\
\hline $\begin{array}{l}\text { Examination every year } \\
\text { regularly }\end{array}$ & 80 & 38.8 & 44 & 21.4 & 71 & 34.5 & 11 & 5.3 & $2.06 \pm 0.97$ \\
\hline Able to BSE & 68 & 33.0 & 44 & 21.4 & 67 & 32.5 & 27 & 13.1 & $2.26 \pm 1.06$ \\
\hline
\end{tabular}

menstrual periods 7 days (51.9\%). More than half of adolescents did not have family with breast cancer (93.2\%). Most respondents were lived with their parent (88.3\%); their monetary allowance were Rp. 15.000,-/days (76.2\%), and family income $\leq$ Rp.3.700.000,(67\%). Most female adolescents got information about breast cancer from the internet/social media (42.7\%) (Table 1).

The respondents had high awareness (67.5\%) (Table 2). The awareness reported different from the previous study, which the adolescents had low breast cancer awareness-the maximum score for "an aggressive disease" (3.28 \pm 0.54$)$ (table 3$)$. The minimum score was risk factors knowledge, "caused of fat" (1.95 \pm 0.69$)$, and BSE, "do BSE in 20th years old and above" $(1.81 \pm 0.78)$, (table 3$)$. Based on the previous study, most adolescents knew that breast cancer is an aggressive disease. Nevertheless, female adolescents had insufficient knowledge of risk factors and BSE (Table 3).

\section{DISCUSSION}

Awareness level is showed in the knowledge of disease (risk factors, signs, and symptoms), feel the changing of their lump. High breast cancer awareness is reported differently from the previous study in which breast cancer awareness in female adolescents (aged $16.2 \pm 0.9$ ) had lower understanding than adult women (aged $34.1 \pm 12.2$ ) (Elshami et al., 2019). High awareness was reported in women aged > 18 years old (Rahman et al., 2019). Most of the adolescents understand that breast cancer is an aggressive disease. They know that they may get breast cancer in the future. So that breast cancer awareness in this study is high.

Adolescents know that breast cancer diagnosed earlier will increase the cure rate, but this is not shown in the perception of good BSE practice. Inadequate breast cancer prevention can be caused by fear if there are signs of lumps and embarrassment in adolescents (Chaka et al., 2018; Elshami et al., 2018). They don't understand that early menarche can be a risk factor for breast cancer in the future. Adolescents need to invited to discuss modifiable risk factors (such as lifestyle factors) and non-modifiable risk factors (genetic, early menarche, hormonal imbalance) for primary prevention of breast cancer (Brennan \& Spillane, 2019)

Female adolescents' majority have lived in Surabaya, which is the capital city of East Java, Indonesia, which includes an urban 
area. The environment also affects somebody to have an awareness of this disease. This results following the research carried out by Idowu that urban areas have easier access to get information and health care than rural areas (Idowu, 2019). The previous research reported that women's knowledge of breast cancer in urban areas was higher than in rural areas (Solikhah, Promthet, \& Hurst, 2019).

Female adolescents have poor knowledge of breast cancer risk factors. This result may be insufficient information about risk factors. In Indonesia, a discussion about reproductive problems is such as taboo. Whereas, a discussion about their reproductive health is necessary. Chronic diseases, such as breast cancer were caused by modified factors recently. Adolescence needs to know that their lifestyle, like physical inactivity, sedentary activity, fast food consumption affects breast cancer in adulthood.

Moreover, nonmodified risk factors are also contributing (genetic, menarche, abnormal period, and abnormal hormone). Department of Health Indonesia has been informed of breast cancer risk factors. However, risk factors such as menarche and abnormal menstrual period have not been reported yet (Mardela et al., 2017).

Female adolescent knows this disease by internet/social media. Nonetheless, their knowledge of risk factors is still low. The internet provides various kinds of information, easily and quickly. However, the information obtained is sometimes invalid or even misleading to adolescents. Improving information about risk factors is needed in this study population.

The female adolescents school in a Vocational High School which do not have studies about health. The school never gave their students a lesson about health nor health counseling. It has adolescent red cross extracurricular, but when the researcher asked the lesson that given, it just learned about first aid. It is recommended that the school should conduct counseling programs about reproductive health.

Breast cancer awareness in this study was described just at that time. While a woman must be aware of it in their span of life since they were menstrual. Their high awareness could not be shown at another time. Their high awareness may be low in another time, so the low awareness in female adolescents may be high. They need healthier behavior modification to avoid breast cancer in the future.

Adolescents still have a long time to learn the importance of breast cancer awareness. They should get a lot of information about breast cancer knowledge, signs and symptoms, risk factors, and the prevention, namely BSE. Health promotion about them should conduct in government, public health, and school.

\section{CONCLUSION}

Breast cancer awareness in female adolescents is high. However, the knowledge of risk factors and BSE is still insufficient. Counseling about women's reproductive health is needed in this population, particularly for breast cancer risk factors and BSE. Preventing breast cancer through a healthy lifestyle such as consume healthy food, increase physical activity, and reduce sedentary lifestyle is necessary. Further researchers must consider another option to observe the awareness level for a longer time.

\section{ACKNOWLEDGEMENT}

Thank all female students who participated in this study. Moreover, the researcher would like to thank the counseling teachers and the principal of Vocational High School V Surabaya for Supporting this research.

\section{CONFLICT OF INTEREST}

The authors declare the absence of conflict of interest

\section{REFERENCES}

Agbokey, F., Kudzawu, E., Dzodzomenyo, M., Ae-Ngibise, K. A., Owusu-Agyei, S., \& Asante, K. P. (2019). Knowledge and Health Seeking Behaviour of Breast Cancer Patients in Ghana. International Journal of Breast Cancer, 2019, 1-9. https://doi.org/10.1155/2019/523984 0

Apriliyana, D., Agusyahbana, F., Mawarni, A., \& Nugroho, D. (2017). Hubungan Persepsi, Paparan Media Informasi Dan Dukungan Orang Tua Dengan Praktik 
Pemeriksaan Payudara Sendiri (Sadari) Pada Remaja Putri Di Sma Negeri 3 Semarang Tahun 2017. Jurnal Kesehatan Masyarakat (e-Journal), 5(4), 207-214. Retrieved from https://ejournal3.undip.ac.id/index.php /jkm/article/view/18347

Cancer Research UK. (2009). Breast Module of the Cancer Awareness Measure.

Chaka, B., Sayed, A., Goeieman, B., \& Rayne, S. (2018). A survey of knowledge and attitudes relating to cervical and breast cancer among women in Ethiopia, 1-9.

Elshami, M., Abu Kmeil, H., Abu-Jazar, M., Mahfouz, I., Ashour, D., Aljamal, A., ... Böttcher, B. (2018). Breast Cancer Awareness and Barriers to Early Presentation in the Gaza-Strip: A CrossSectional Study. Journal of Global Oncology, (4), 1-13. https://doi.org/10.1200/JG0.18.00095

Elshami, M., Kmeil, H. A., Abu-jazar, M., Mahfouz, I., Ashour, D., Aljamal, A., ... Bottcher, B. (2019). Breast Cancer Awareness and Barriers to Early Presentation in the Gaza-Strip : A CrossSectional Study. Journal of Global Oncology.

Idowu, A. (2019). Breast cancer awareness , knowledge and screening practice among women resident in an urban local government area of Oyo State, Nigeria. Journal of Cancer Policy, 20(August 2018), 100179. https://doi.org/10.1016/j.jcpo.2018.11. 001

Katkuri, S., \& Gorantla, M. (2018). Awareness about breast cancer among women aged 15 years and above in urban slums: a cross sectional study. International Journal Of Community Medicine And Public Health, 5(3), 929. https://doi.org/10.18203/23946040.ijcmph20180461

Kemenkes RI. (2016). Infodatin: Kanker Payudara. Jakarta.

Kemenkes RI. (2018). Riskesdas 2018. Jakarta.

Liu, L., Wang, Y., Wang, F., Yu, L., Xiang, Y.,
Zhou, F., ... Wang, F. (2018). Factors associated with insufficient awareness of breast cancer among women in Northern and Eastern China: a case - control study.

https://doi.org/10.1136/bmjopen2017-018523

Luzzati, T., Parenti, A., \& Rughi, T. (2018). Economic Growth and Cancer Incidence. Ecological Economics, 146(November 2017), 381-396. https://doi.org/10.1016/j.ecolecon.201 7.11.031

Mahajan, M., Naik, N., Jain, K., Patira, N., Prasad, S., Mogri, S., ... Basu, P. (2019). Study of Knowledge, Attitudes, and Practices Toward Risk Factors and Early Detection of Non-communicable Diseases Among Rural Women in India. Journal of Global Oncology, (5), 1-10. https://doi.org/10.1200/JG0.18.00181

Mardela, A. P., Maneewat, K., \& Sangchan, H. (2017). Breast cancer awareness among Indonesian women at moderate-to-high risk. Nursing \& Health Sciences, 19(3), 301-306. https://doi.org/10.1111/nhs.12345

Momenimovahed, Z., \& Salehiniya, H. (2019). Epidemiological characteristics of and risk factors for breast cancer in the world. Breast Cancer: Targets and Therapy, Volume 11, 151-164. https://doi.org/10.2147/bctt.s176070

Rahman, S. A., Marzouki, A. Al, Otim, M., Hoda, N. El, Khayat, K., Yousef, R., \& Rahman, P. (2019). Awareness about Breast Cancer and Breast Self-Examination among Female Students at the University of Sharjah: A Cross-Sectional Study, 20, 1901-1908.

https://doi.org/10.31557/APJCP.2019. 20.6.1901

Sama, C.-B., Dzekem, B., Kehbila, J., Ekabe, C. J., Vofo, B., Abua, N. L., ... III, F. A. (2017). Awareness of breast cancer and breast self-examination among female undergraduate students in a higher teachers training college in Cameroon. Pan African Medical Journal, 28. https://doi.org/10.11604/pamj.2017.2 8.91.10986 
Sayed, S., Ngugi, A. K., Mahoney, M. R., Kurji, J., Talib, Z. M., Macfarlane, S. B., ... Moloo, Z. (2019). Breast Cancer knowledge, perceptions and practices in a rural Community in Coastal Kenya. BMC Public Health, 19(1), 180. https://doi.org/10.1186/s12889-0196464-3

Singam, K. K., \& Wirakusuma, I. B. (2017). Gambaran tingkat pengetahuan dan perilaku tentang pemeriksaan payudara sendiri ( SADARI ) pada remaja putri di wilayah kerja UPT Puskesmas Blahbatuh II Gianyar Bali Indonesia, 8(3), 184-188. https://doi.org/10.1556/ism.v8i3.135

Solikhah, S., Promthet, S., \& Hurst, C. (2019). Awareness Level about Breast Cancer
Risk Factors, Barriers, Attitude and Breast Cancer Screening among Indonesian Women. Asian Pacific Journal of Cancer Prevention, 20(3), 877-884. https://doi.org/10.31557/APJCP.2019. 20.3.877

WHO. (2010). Global Recommendations on Physical Activity For Health.

WHO. (2013). Global Action Plan For the Prevention and Control Noncommunicable Diseases: 2013-2020.

WHO. (2019a). Breast.

WHO. (2019b). Internasional Ageing for Research on Cancer: Indonesia fact sheets, 256, 2018-2019. 